\title{
A Visit to Some Music Libraries in Eastern Europe
}

The author relates a kind of travelog of his visits to music libraries in Yugoslavia, Rumania, and Hungary. He describes collections, organization, staffing patterns, physical plants, gives brief historical notes, and general impressions from his tour. The trip was made in preparation for a projected "Guide to European Music Libraries and Collections."

I surT of materials and information for a "Guide to European Music Libraries and Collections," most of the summer of 1966 was spent in Europe visiting national libraries. ${ }^{1}$ My schedule called for me to be in eastern Europe in September. Since Dragan Plamenac's excellent report of $1961^{2}$ covered Poland, East Germany, and Czechoslovakia, I planned to concentrate on Yugoslavia, Rumania, and Hungary.

Proceeding south and east from Basel, Switzerland, my home base, my first stop was Belgrade. Here my attention was first directed to the Narodna Biblioteka, which is housed in an old and inadequate building (on the Knez Mihailova, 56). The National Library was badly damaged during the war, and there are plans to build a new structure to house the collections. The music holdings are very small. Apparently collecting in this area, particularly in musicology, is being left to the Muzikoloski Institut of the Srpska Akademija Nauka (Musicological

1 The author wishes to express his appreciation to the Ohio State University for a grant in support of research and travel for the "Guide." The present article is drawn from the lecture "European Musicology and Music Libraries, Summer 1966," delivered at the State University of New York at Buffalo, November 2, 1966.

"See his "Music Libraries in Eastern Europe; A Visit in the Summer of 1961," Music Library Association Notes, XIX (1961-62), 217-34, 411-20, and 584-98.

Mr. Mixter is Associate Professor of Music History and Literature in Ohio State University.
Institute of the Serbian Academy of Sciences, Knez Mihailova, 35). Even here, however, the holdings are modest, numbering about one hundred journals, 2,682 books, 1,822 pieces of music, and about six hundred records. As in most Slavic countries, much attention is given to folk music. The Institute serves the university, as well as other scholarly musical interests in Belgrade. One gets the impression that support for libraries in this city is not strong, but that personnel are working very hard to make do with what they have.

My last library visit in the capital was paid to the Muzicka Akademija (the Conservatory, Ulitza Maršala Tita, 50). Efficiency and organization were more in evidence here than in any other library in Belgrade. The collection numbers about thirty thousand volumes and is designed, of course, to support the musical activities of the Conservatory. It appears that much of the instruction in music history and theory here, as well as at the sister institution in Bucharest, is carried on through the use of mimeographed texts written by the teachers themselves; these texts are found in the libraries in multiple copies. The present card catalog for music is handwritten, but new typed cards are in preparation. The use of the Cyrillic alphabet is a hindrance, for since most of the performance music is published in the West, two catalogs are 
necessary, one in the Latin and one in the Cyrillic alphabets.

An overnight train journey brought me into Bucharest about seven in the morning. Following a frustrating wait for a hotel room in the central government tourist office, I deposited my luggage and embarked upon a quest for music libraries. Public transportation is minimal in this city; indeed, one sees considerably fewer vehicles in general than in the West, and many of these are military. The reception accorded me in the libraries was most cordial. My first visit was to the Biblioteca Centrală de Stat (str. Ion Ghica, 4). One of the librarians at this national library, Mr. Samuel Katz, proved to be very knowledgeable in musical affairs, for he is a graduate of the Conservatory and had served for many years as a conductor. While talking about the library, he strongly emphasized its mission of service to the people. In the music division this is exemplified by periodic music appreciation hours, consisting of a discussion of the composer's life and works and the playing of selected compositions. The music room is equipped with several earphone listening posts (although in the actual lectures speakers are used) and a record and tape library. Mr. Katz was most helpful in providing information about important collections outside $\mathrm{Bu}$ charest.

At the Biblioteca Centrală Universitaria (Onesta, 1) a student of architecture, who could speak French rather well, gave freely of his time in showing me the library and its collections and in introducing me to responsible authorities. The music holdings of the university library are small, although both here and in the Conservatory library a proud acquisition, for obvious reasons, is a facsimile edition of George Enescu's opera Oedipe.

The Conservatorul "Ciprian Porumbescu" (Str. Stirbei Vodă, Nr. 33) is named after the distinguished Rumanian composer of the second half of the nine- teenth century, a pupil of Bruckner in Vienna. ${ }^{3}$ Porumbescu is perhaps unique in the annals of music history, for the name of the place of death of this composer and political martyr has been changed to "Ciprian Porumbescu"!

At the time of my visit, the Conservatory was undergoing considerable renovation, and work was being hastened to meet the opening of classes. Young women were conspicuous among the workers engaged in this task. The library is a closed collection, and the volumes are shelved by size in four categories. This seems to be a favored arrangement in closed collections in Europe. As in the national library, the works of Lenin and other Communist leaders are prominent. I was told that ordering is done through a central agency, and that while European publications can be readily acquired, those from the United States are difficult, if not impossible, to obtain. The library enjoys the services of a translator who apparently translates foreign language publications into Rumanian for the students. The card catalogs consist of one for books, by author, and one for music, both systematic and by composer. The catalog of compositions by Rumanian composers is being abandoned. The holdings number 560 periodicals, 11,400 books, 44,000 volumes of music, and 300 manuscripts. The Conservatory emphasizes opera production, and toward this end has studios for stage design and photography which are professionally staffed.

Before departing from Bucharest I paid a visit to the Biblioteca Academiei (Calea Victoriei, 125). The academy posesses about twenty-five thousand printed scores and six thousand eight hundred musical manuscripts. Where the national libraries are assuming more and more the function of "people's libraries," as in Belgrade and Bucharest, the academy li-

'A history of the Conservatory is given in the volume Conservatorul "Ciprian Porumbescu," 1864-1964 (Bucharest, 1964). A bio-bibliography of prominent Rumanian musical figures is Viorel Cosma's Compozitori si Muzicologi Români; Mic Lexicon ([Bucharest], 1965 ). 
braries are being made responsible for scholarly collecting. A word of warning to those who might expect to work in libraries in Rumania: special collections and those responsible for them are accessible for the most part only in the morning!

An overnight train, leaving at midnight, brought me into Budapest in the early afternoon. Because of the weekend I was able to visit just one library, the music division of the Orszagos Széchényi Könyvtár (Pollack Mihály-tér 10, actually in Pest). Although it is possible to trace the spirit of the national Széchényi library back to the famous Biblioteca Corvina of the fifteenth-century King Mátyás, the real foundation of this institution is the endowment of Count Ferenc Széchényi, who, from 1802 to 1807 , gave twelve thousand items from his private collection to the national library. For many years the museum and library were united, but they have now been separate since 1949. The character of the library today is guided by the principle that it should act as a collector of Hungarian books, and this is accomplished mainly by deposit laws. The library also functions as library administrator for the nation. The collections are presently very inadequately housed, but the personnel are looking forward to a magnificent new situation in the old Royal Palace overlooking the Danube on the Buda side.

Although music material in the strict sense has been collected since about 1900 , the music division was first established in 1929. It is headed by Jenö Vécsey, who was very ably represented during his illness at the time of my visit by István Kecskeméti. The basic material falls into three parts: manuscripts, prints, and recordings. Books and peripheral material are in the main collection of the national library. The division itself is strong in Renaissance and Baroque music, especially in the Bártfa collection, ${ }^{4}$ and in the Vienna classics. The latter

4See Hans Albrecht, "Bartfeld," Die Musik in Geschichte und Gegenwart (Kassel, 1949-), I, 1342-45. area boasts not only many autograph Haydn scores, ${ }^{5}$ but also strength in such composers as Gregorius Joseph Werner, Michael Haydn, Johann Georg Albrechtsberger, Karl Ditters von Dittersdorf, and Franz Xaver Süssmayr. ${ }^{6}$ Of particular importance is the famous Esterházy Archive. ${ }^{7}$ Although nineteenth-century composers such as Schubert and Schumann are represented in both manuscript and first edition, local association is more typical of nineteenth- and twentieth-century figures such Liszt, Ference Erkel (the composer of the Hungarian national anthem), Bartók, Kódaly, and Dohnányi. ${ }^{8}$ The old printed catalog of manuscript music ${ }^{9}$ is supplemented by continuations on cards. There are also card catalogs for the reference library, books on music, prints, the Esterházy collection, Hungarian text incipits, series, and records, as well as a quick reference catalog for the principal composers. Several publication series and selected recordings are emanating from the national library music collection, including "Musica Rinata" and "Serate d'opere di Esterháza." In spite of inadequate housing I received the impression that there is strong support for the library.

The train journey from Budapest to Vienna, from which point I was to continue my tour, was a rather short one. By making it, one recovers some of the cultural rapport which existed between these two metropolitan centers before World War II and which is so strongly in evidence in our musical heritage.

5 The reader is referred to the handsome volume edited by Jenö Vécsey, Haydn Compositions in the Music Collection of the National Széchénye Library, Budapest (Budapest, 1960).

"See I. Kecsweméte, "Süssmayr-Handschriften in der Nationalbibliothek Széchényi, Budapest," Studia Musicologica, II (1962), 283-377.

"A "Catalogue raisonné" of the Esterházy opera collection may be found in D. Bartha and L. Somfai, Haydn als Opernkapellmeister (Budapest, 1960), 177378 .

'See, for example, I. Kecskeméti, "Unbekannte Eigenschrift der XVIII. Rhapsodie von Franz Liszt," Studia Musicologica, III (1962), 173-79.

' Isoz Kalmán and Lavotte Rezsö, Zenei kéziratok jegyzéke (Budapest, 1921-40, 2 vols. 